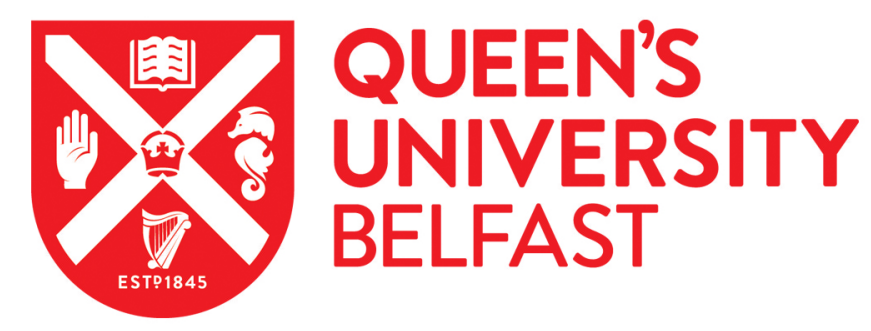

\title{
An Investigation into Tenacity Levels at CoderDojos1
}

McKelvey, N., \& Cowan, P. (2017). An Investigation into Tenacity Levels at CoderDojos1. International Journal of Innovation in the Digital Economy, 8(3), 35-48. https://doi.org/10.4018/IJIDE.2017070103

Published in:

International Journal of Innovation in the Digital Economy

Document Version:

Publisher's PDF, also known as Version of record

Queen's University Belfast - Research Portal:

Link to publication record in Queen's University Belfast Research Portal

Publisher rights

Copyright 2017 IGI Global.

This work is made available online in accordance with the publisher's policies. Please refer to any applicable terms of use of the publisher.

\section{General rights}

Copyright for the publications made accessible via the Queen's University Belfast Research Portal is retained by the author(s) and / or other copyright owners and it is a condition of accessing these publications that users recognise and abide by the legal requirements associated with these rights.

Take down policy

The Research Portal is Queen's institutional repository that provides access to Queen's research output. Every effort has been made to ensure that content in the Research Portal does not infringe any person's rights, or applicable UK laws. If you discover content in the Research Portal that you believe breaches copyright or violates any law, please contact openaccess@qub.ac.uk. 


\title{
An Investigation into Tenacity Levels at CoderDojos
}

\author{
Abstract-This paper provides an overview of CoderDojos and the philosophy that it \\ aspires to. The research was conducted in Co Donegal, Ireland and focused on four \\ CoderDojo locations that were geographically disperse. The findings used a scale \\ known as Grit in order to gauge the tenacity levels of children attending these Dojos. \\ Comparisons were drawn between genders. It also provides a rationale for future \\ research with the addition of qualitative methods.
}

\section{Index Terms-CoderDojo, Gender, Grit, Tenacity}

\section{INTRODUCTION}

There have been many policy reports in the past decade or more (NRC, 1999; ITEEA, 2000; NAENRC, 2002) which have highlighted a growing concern about the lack of knowledge surrounding technology among communities. In an attempt to address the concerns raised, the reports called for initiatives to be established that might impart these skills to more people. The National Research Council (NRC) report defined "fluency" about technology as "the ability to reformulate knowledge, to express oneself creatively and appropriately, and to produce and generate information (rather than simply to comprehend it)." The report went further to suggest that fluency "goes beyond traditional notions of computer literacy...[It] requires a deeper, more essential understanding and mastery of information technology for information processing, communication, and problem solving than does computer literacy as traditionally defined". Improving "technological fluency" traditionally focused on the classroom, more specifically the classrooms in Higher Education (Resnick, 2002). However, the last decade has witnessed an increasing recognition that more informal settings and after-school environments could play an increased role in disseminating these skills and bring technology to the fore within communities. The National Academy of Engineering and National Research Council report (NAENRC, 2002) outlined that, "The informal education system must become a major focus" for promoting fluency. The NSF Directorate for Education and Human Resources describes informal learning as "self-directed, voluntary, and motivated mainly by intrinsic interests, curiosity, exploration, and social interaction." Therefore, initiatives such as the CoderDojo as an informal-learning setting is well suited in helping young people explore and experience with technology in a way that may lead to an increase in technological fluency.

A CoderDojo is a global network of free, volunteer-led, independent, community based computer programming clubs for young people. These young people (Ninjas), aged between 7 and 17 years, learn how to code, develop websites, build mobile applications or games and explore technology in an informal and creative environment. In addition to learning how to code, attendees meet like-minded people and gain skills in team work, collaboration, problem solving as well as confidence building.

"One rule, be cool!"

"Ask 3 then me!"

"If you made it you can play it!"

"No idea is a bad idea and there is no such thing as failure!" (ECHO, 2015). The quotations serve to emphasize the philosophy within CoderDojos where games based learning features, independent learning is fostered and creativity is encouraged. 


\section{ORIGINS OF CODERDOJOS}

The CoderDojo is a global movement which was originally founded by James Whelton and Bill Liao (CoderDojo, 2015). Its genesis was in James Whelton's school in early 2011 when James received notoriety as a result of hacking the iPod Nano. Due to its publicity, other younger students became interested in learning how to code. James then established a computer club in his school (PBC Cork) and began tutoring in some basic website development. As a result of the club's popularity he then met Bill Liao, an entrepreneur and philanthropist, who saw the positive potential in these coding clubs and sought to grow the project into something bigger. The movement is open source (free) with thousands of dedicated mentors forming CoderDojos all over the world, making the CoderDojo movement a global phenomenon. As of May 2015 there were in excess of 675 verified CoderDojos in 57 countries and growing every day (CoderDojo, 2015).

The global CoderDojo community is supported by the CoderDojo Foundation which consists of a core team based predominantly in Dublin, Ireland. The Foundation was established by one of the initial CoderDojo founders James Whelton and is focused on supporting new and existing CoderDojos through resource and community development. The group aims to create global awareness amongst young people of programming.

The ECHO (Ethos, Culture, Happiness and Outcomes) as presented by the CoderDojo Foundation in 2015 establishes the philosophy of the movement (ECHO, 2015). The Foundation suggests that their document acts as a guide as opposed to a pedagogy and is devised through the contributions of the children, the community, tutors and academic experts. $\mathrm{ECHO}$ advocates that there is collaboration, teamwork, volunteers from the community, mottos for each Dojo. They advocate- that it is inclusive, fun, informal, free, self-led and that it utilises and remains open source. With young people given responsibilities in their respective CoderDojos, the aim is that confidence levels will be raised along with communication and leadership skills.

\section{Challenging the Orthodoxies}

According to Downes (2006) and Siemens (2006), a core source of engagement in education is knowledge itself which has become ever more fluid. Kress and Pachler (2007) have stated, "what we have here is a transition from a stable, settled world of knowledge produced by authority/authors, to a world of instability, flux, of knowledge produced by the individual" (p207). The notion of organised knowledge clearly defined by experts is, in some instances, being sidestepped to give way to continual flux. Many (Gorman, 2007; Keen, 2007) consider this view of knowledge as controversial and also consider it to be challenged by individuals finding the move from expert to amateur knowledge producers unsettling. Siemens (2008) outlines that the view of experts as sole providers and evaluators of information is one which cannot be sustained in this world of ever advancing technology. Society are persistently exposed to a continual flow of data which enables people to build new concepts and gain new knowledge in new ways.

Research highlights that many are placing importance on the need for differential approaches to both content delivery and learning so that optimum intellectual development can be fostered (Bridges and Hallinger, 1995; Garry, 1963; Gregory and Chapman, 2002; Paul and Elder, 2005). Striking a balance between critical thinking and creativity is presented as being essential in the construction of knowledge where a single solution to a problem is not the answer (Blackbourn, et al., 2011).

Crebbin (2004) outlines, that a within a constructivist learning environment (such as a CoderDojo), there is a need for:

- Knowledge construction, not reproduction

- Working with real word knowledge 
- Realistic and relevant real world environments

- Emphasis on many representations and interpretations that recognise varying perspectives

- Collaboration and social negotiations

- Metacognition and reflection on learning

- Self regulated learning

- Negotiated goals

- Evaluation as self-analysis

The concept of fluidity as outlined by Boyer et al. (2003) is one that can help with theorizing the topology of a CoderDojo. Conventional learning spaces tend to involve teacher led instructions, rigid learning outcomes, memorising facts, standardised tests, an isolated classroom dissected from the real world and a focus on individual achievement (Kouritzin, et al., 2009). The new and unorthodox learning environment offered by CoderDojos are learner centred with hands-on practical experience, problem based and project oriented. The traditional teacher role is also replaced by one where a tutor or computer programming professional leads and guides without a steadfast structure and without facilitating a classroom hierarchy. There is a fluidity present where interconnections and interrelations between learners and any other actor involved are fostered and encouraged when learning occurs (Boyer, et al., 2003). The CoderDojo environment appears to cross the traditional student/teacher boundaries as well as the usual boundaries that exist between an individual and a collective. Kouritzin, et al. (2009) suggest that the theory of fluidity in a learning environment can create transformations with discontinuities.

\section{Profile AND Diversity OF CoderDojo Ninjas}

While a typical CoderDojo has young people between 7 and 17 years of age participating, it is not a strict rule per se with other CoderDojos extending the lower age limit of 7 to younger children. The Foundation does not stipulate any age, only that participants should have an ability to read basic words and understand how to spell commands. The mix of ages typically enhances the experience of Ninjas as younger children learn from more experience and knowledgeable older children while the older children learn how to interact with and mentor their younger counterparts. The social aspect of the CoderDojo tends to bridge the age gap.

CoderDojos exist throughout the world but can only really exist in an area where there is a sufficient level of technology and a Champion (an individual to establish the CoderDojo). As a result, globally, CoderDojos reach a diverse range of children in terms of their geographic location, level of skill, age and gender.

It is well documented that computing tends to attract more males than females (McKelvey, 2013; Yardi and Bruckman, 2007) with CoderDojos attracting on average $30 \%$ females according to the Foundation's 2015 report (CoderDojo, 2015). While 30\% appears to be a relatively low number, the average female employment in computing tends to hover around $20 \%$. The figures are averages however, with many CoderDojos exceeding the $30 \%$ mark. The questions remains, why do males favour computing more than females? Are there predominantly male traits needed to be an effective programmer?

\section{FORMAL, INFORMAL AND UNFORMAL LEARNING}

Rogers (2004) noted that in the 1990s, attention given to non-formal education was reluctant and hesitant. As the post-Jomtien ${ }^{1}$ era focused heavily on formal education, governments and agencies have, as a result, exhibited little interest in non-formal education (Hoppers, 2006). 
The exception, however, to this stance is that of agencies concerned about the social conditions of marginalised children and young people such as the United Nations Children's Fund (UNICEF) and Save the Children (SCF). In the current post-Dakar ${ }^{2}$ decade, opinions are evolving again. There are indications that non-formal education, at various levels and for various groups, is gaining in popularity. In recent times, several development agencies, such as the Swedish International Development Cooperation Agency (Sida) and the World Bank, have reassessed their position on adult education in particular (Lind, 2002; Torres, 2003; Oxenham, et al., 2002; Rogers, 2004). In addition to UNICEF and SCF, other agencies have given their support for the provision of non-formal education to children and young people, such as the United States Agency for International Development (USAID), the Netherlands, Ireland and Switzerland (Hoppers, 2006).

Controlling one's own learning aligns with the CoderDojo philosophy. Ward, et al. (1974) posit that, "Piaget, Freire, Havighurst, Colemam, Brookover and literally hundreds of other psychologists, educators, sociologists and philosophers have indicated clearly where education should be and where, instead it wallows in inefficiency, crust rigidity and stubbornness. Most of those critics advocate changes of the existing educational system and there is ample evidence of the need for dramatic efforts in this area." Agency in learning via an informal or unformal approach may be the catalyst required. For agency to be achieved, the approach to content delivery must evolve.

\begin{tabular}{|c|c|c|c|}
\hline \multicolumn{2}{|c|}{ Formal } & Informal & Unformal \\
\hline Examples & $\begin{array}{l}\text { Visits to } \\
\text { museums or to } \\
\text { scientific and } \\
\text { other fairs and } \\
\text { exhibits with a } \\
\text { report required } \\
\text { by students } \\
\text { afterwards or } \\
\text { an associated } \\
\text { assessment. }\end{array}$ & $\begin{array}{l}\text { visits to museums or to } \\
\text { scientific and other fairs } \\
\text { and exhibits } \\
\text { - listening to radio } \\
\text { broadcasting or watching } \\
\text { TV programmes on } \\
\text { educational or scientific } \\
\text { themes } \\
\text { reading texts on } \\
\text { sciences, education, } \\
\text { technology, etc. in } \\
\text { journals and magazines } \\
\text { participating in scientific } \\
\text { contests } \\
\text { attending lectures and } \\
\text { conferences }\end{array}$ & $\begin{array}{l}\text { - Subject matter } \\
\text { experts present to } \\
\text { answer questions but } \\
\text { are not trained } \\
\text { educators } \\
\text { - Agency - students } \\
\text { decide themselves } \\
\text { how to resolve a } \\
\text { problem. } \\
\text { Unstructured/fluid } \\
\text { learning not following } \\
\text { a curriculum } \\
\text { No assessment }\end{array}$ \\
\hline
\end{tabular}

Table 1 Formal, Informal and Unformal Learning (Dib, 1988)

Dib (1988) augurs that the success of an unformal learning environment is dependent upon the level of motivation amongst the students and the quality of materials utilised so as to uphold the motivation levels ensuring that the expectations of the individuals are met. Finally, the provision of nonformal institutions with support of a multidisciplinary team is important in enabling the environment to continue with longevity.

\section{SPATIAL THINKING}

When learning computer programming in HE, students are encouraged to 'design on paper' before coding in a development environment (Wirfs-Brock and Johnson, 1990). Common diagrammatic representations of code include entity relationship diagrams, data flow 
diagrams, class diagrams and indeed sequence diagrams. At CoderDojos, children are also encouraged to design their program before physically typing it up. The purpose is that time is spent considering the various required components and how they might link together. While formal notation of the diagrams are not enforced, the result is that children can often mentally manipulate the symbolic representations of their code via these diagrams. In essence the spatial skills can impact upon the learning and understanding. Wiley and Jee (2011) suggest that those with acute spatial skills will exhibit bodily gestures to accompany their articulation and understanding of the concepts. Where there are gestures in conjunction with code explanations even though verbal articulation is poor, then there is a suggestion that the child is well prepared to learn a complex concept.

\section{Dialogic Approaches}

It is arguable that creativity can be viewed as an individual phenomenon with the discourse of creativity focusing on the personality (Montuori, 1998). It is the author's opinion however that creativity can be encouraged and become infectious by the adoption of a natural dialogic approach to learning.

CoderDojo interactions encourage students to think and to think in ways which challenge their own pre-conceived notions of learning. The questions and problems presented to the children invite more than simple recall. As all participants are considered peers, answers are justified, followed up and built upon rather than merely received. The feedback given should inform and lead thinking forward as well as encourage the children. Contributions by both tutor and learner are extended rather than fragmented in a CoderDojo which results in exchanges that combine into coherent and deepening lines of enquiry. The philosophy advocates discussion and argumentation which probe and challenge rather than have learners unquestioningly accept answers and methods. By acknowledging that children can learn complex concepts, a CoderDojo has professional engagement with the subject matter via its tutors which liberates classroom discourse from the safe and conventional. This also goes some way towards breaking down the traditional classroom hierarchy and structure which has the potential to inhibit creativity. It is this classroom organisation, climate and relationships which make a comfortable learning environment as a result of a considered dialogic approach.

\section{FAR TRANSFER}

Instruction often entails the promotion of learning with a goal of enabling students to transfer their existing knowledge in novel ways which is typically dissimilar to their initial learning styles or contexts (Wiley and Jee, 2011). The result can be referred to as far transfer. A CoderDojo setting is a good example of far transfer in operation where learners approach resolving an issue in a manner which is familiar but given the nature of a CoderDojo and its philosophy, inevitably forces a child to think outside the box and take their familiar strategies to a new level. As a lecturer in computer science, the researcher has anecdotal evidence to suggest that lecturers in the field often debate whether one should teach syntax and code first or teach concepts first, with the view to coding later. Goldstone et al (2008) suggest that when a lesson is taught using concrete examples which evolve into something more abstract, then students are more likely to be in a position where they can transfer the principle to some new context. However, Wiley and Jee (2011) augur that a more beneficial acquisition of knowledge can be attained where the lesson commences with abstract or symbolic representations of a concept which aids learning and transfer. 


\section{ENVIRONMENTAL INFLUENCES ON LEARNING}

When combined with learning, it is the author's opinion that extracurricular activities have the potential to help students raise their self-esteem. Given the nature of CoderDojos, this is further enhanced as the children have opportunity to connect with the adults in the community in a positive manner. However, not all CoderDojos take place in the same environment. Some take place in youth centres or family resource centres, others take place in secondary schools, some in primary schools and others in industrial settings. For the movement to be successful, it raises the question if the learning environment is an important factor.

Fredricks and Eccles (2006) posit that extracurricular participation can be attributed to positive academic outcomes such as an improvement in academic achievement (grades), improved school engagement and a noted increase in the children's educational aspirations. Conversely, Eccles and Barber (1999) present possible negative consequences with some extracurricular activities particularly where a tutor uses negative language or if team members exclude others. Morrissey (2005) outlines that positive youth development encompasses five traits or characteristics: (1) competence in academic, social and vocational areas; (2) confidence; (3) connection to family, community and peers; (4) character; (5) caring and compassion.

Absorption in learning can happen as a result of participation in learning which aligns with the cultural-historical activity theory (Morf and Weber, 2000). The theory suggests that what we know evolves out of participation in activities within the community. Humans are co-creators of their conditions and are not simply subjected to it. This invariably implies that learners can be co-creators of their own learning environment also.

\section{HeURISTIC AND Holistic LEARNING}

The practical implementation of an approach which is holistic requires a tutor who is dedicated and who possesses a genuine interest in the learner (Patel, 2003). At a CoderDojo, tutors are encouraged to demonstrate a willingness to elicit and engage with learners' personal approaches to learning. A holistic tutor is one who genuinely wishes to engage with the young people in developing a learner into a critical thinker who is inspired by their social environment.

With the traditional didactic approaches often adopted by educationalists, a learner's personal epistemology or their own approaches are, largely, considered irrelevant (Banning, 2005). In such a classroom setting, the learners are expected to simply receive the knowledge imparted to them. Often it requires that a student regurgitates or recalls a list of bullet points, a paragraph or an essay learned by heart. In schools and universities, educationalists are under pressure to glide through a curriculum/syllabus inside a very short timeframe and to produce the necessary grades. A primary advantage offered by a CoderDojo is that there is no set curriculum and no exam or test. Therefore, learners are afforded the opportunity to reflect and to critically analyse problems presented to them.

Teaching is "no longer seen as imparting knowledge and doing things to the student, but is redefined as facilitation of self-directed learning" (Tight, 1996, p26). Burgess and Taylor (2005) outline how "active learning" provides a shift from the didactic methods and ensures student participation. Active learning, incorporates problem solving skills which involves higher order cognitive activities (Burgess and Taylor, 2005). The approach involves the educator providing learners with a range of activities with minimal dialogue required between the student and tutor. Biggs (1999) suggests that the reduction in dialogue is acceptable as the learning is an individual and cognitive process. 


\section{RESEARCH QUESTION}

The research conducted for this paper endeavored to gauge the tenacity levels that existed among the children attending four purposively sampled CoderDojos in County Donegal, Ireland. The tenacity levels were gathered using an 8-point Likert scale known as the Grit Scale (Duckworth and Quinn, 2009). The study also analysed whether differences existed between grit scores of the genders attending these CoderDojos.

\section{TENACITY}

Howe (1999) disputes the notion that high achievement is derived from exceptional mental ability, rather "perseverance is at least as crucial as intelligence.... The most crucial inherent differences may be ones of temperament rather than of intellect as such" (p15). Therefore, the goal at a CoderDojo is not to gain high grades in assessments but rather to provide the learner with lifelong skills in tenacity which, arguably, is just as an important factor in success as intelligence

Recent trends in how people learn can be attributed to the dispositions that people have when entering into a learning environment. Duckworth and Quinn (2009) outline characteristics of a trait known as Grit where learners exude a determination in completing a task. Other research has investigated characteristics such as:

- Perseverance and Tenacity

- Deliberate Practice

- Ability to Delay Gratification

- Passion-Driven Focus

- Self-Control and Self Discipline

- Long Term Goal-Oriented

- Stick-to-it-ness Under Difficult Conditions

- Consistency of Effort

In order to facilitate and foster grit, Gerstein (2013) suggests that learners should be engaged with long term activities that are project based which may or may not require teams. The task at hand should require independent study specific to their own passions and interests.

The Perseverance Scale for Children by Lufti and Cohen (1987) was reviewed as a potential scale to measure how determined children at a CoderDojo are when solving difficult problems. The scale was dismissed however, for this study, as it included 40 items which was deemed to be potentially too time consuming for the primary aged pupils to complete fully. The reliability of the scale had a Cronbach alpha value of .66 which would have required consideration. The Passion Scale (Vallerand, et al., 2003) assesses commitment to a subjectively important activity but omit to capture perseverance of effort. The Tenacity Scale used by Baum and Locke (2004) and derived from Gartner, Gatewood and Shaver (1991) was developed for entrepreneurs and was deemed to lack face validity for children or adolescents. As a result, the eight item Grit scale as presented by Duckworth, et al. (2007) was selected. The measurement has acceptable internal consistency with alpha values in the range .73 to .83.

\section{Methodology}

While it was necessary to gauge the opinions of the children themselves about their CoderDojo, it was also an opportunity to gauge whether or not the children attending these Dojos possessed the characteristic of tenacity. Questionnaires provide advantages in that they offer a set of structured data which can be administered without the researcher being present and are easily analysed (Wilson and McClean, 1994). The questionnaire was identified due to its succinctness and Cronbach's alpha score and was administered prior to focus group interviews. This paper will focus on the results of Grit Survey only. The research was conducted ethically with informed consent gained from relevant gatekeepers, parents and Dojo Ninjas. 


\section{RELIABILITY AND VALIDITY: GRIT}

Ensuring that the data collected was both valid and reliable was an important consideration in order to reduce errors and to provide data that would add to the research in this area. It was necessary to consider if the questions were adequately assessing grit. The Cronbach's $\alpha$ values are stipulated in the results section. A tried and tested mechanism of assessing Grit (tenacity) was adopted in the form of the Grit scale. The scale is a five point Likert where participants responded with Very much like me, Mostly like me, Somewhat like me, Not much like me, Not like me at all. With the scale designed specifically for children, it was deemed to be an appropriate measure. The purpose of the scale was to determine if all those who attend a CoderDojo showed levels of high grit. Multiple questions in this area went some way to achieving internal reliability of the survey but the content validity fell short as many other areas could have been explored such as attitudes toward working from home, technology, studying online and attitudes towards team work.

After the internal reliability review, it was necessary to conduct an external review. The external reliability of the questionnaire was assessed through a pilot where an established CoderDojo took the survey. The participants highlighted potential issues where some of the words used may have been difficult to understand. Therefore, synonyms were placed in brackets beside to help the children complete the survey unaided. This helped the reliability of the data and reduced the potential for errors to occur (Connolly, 2007).

Analysis was then conducted using SPSS version 22.

\section{Results AND ANALYSIS}

A purposive sample of four distinct CoderDojos was used. The following table outlines the profile of each CoderDojo researched:

\begin{tabular}{|c|c|c|c|}
\hline CoderDojo ID & Environment & Tutor Profile & $\begin{array}{l}\text { Technologies } \\
\text { Used }\end{array}$ \\
\hline A & $\begin{array}{l}\text { Secondary school } \\
\text { computer lab. Out of } \\
\text { school hours. Primary } \\
\text { school children in } \\
\text { attendance. Fridays. }\end{array}$ & $\begin{array}{l}\text { Six computer } \\
\text { science } \\
\text { degree } \\
\text { student } \\
\text { volunteers. }\end{array}$ & $\begin{array}{l}\text { Scratch, } \\
\text { HTML, } \\
\text { Minecraft }\end{array}$ \\
\hline B & $\begin{array}{l}\text { Family Resource Centre. } \\
\text { Saturdays. }\end{array}$ & $\begin{array}{l}\text { Computer } \\
\text { Programmers. }\end{array}$ & $\begin{array}{l}\text { Scratch, } \\
\text { HTML, } \\
\text { JavaScript, } \\
\text { Python }\end{array}$ \\
\hline C & $\begin{array}{l}\text { Primary School classroom } \\
\text { - during school time. } \\
\text { Fridays. }\end{array}$ & $\begin{array}{l}\text { Usual class } \\
\text { teacher with } \\
\text { the addition of } \\
\text { two computer } \\
\text { science }\end{array}$ & Scratch \\
\hline
\end{tabular}




\begin{tabular}{|c|c|c|c|}
\hline & & $\begin{array}{l}\text { degree } \\
\text { students } \\
\text { volunteering }\end{array}$ & \\
\hline D & $\begin{array}{l}\text { Secondary school } \\
\text { computer lab. Out of } \\
\text { school hours. Primary } \\
\text { school children in } \\
\text { attendance. Mondays. }\end{array}$ & $\begin{array}{l}\text { Computer } \\
\text { Programmers. } \\
\text { Computer } \\
\text { science } \\
\text { degree } \\
\text { student } \\
\text { volunteers. }\end{array}$ & $\begin{array}{l}\text { Scratch, } \\
\text { HTML, CSS } \\
\text { JavaScript, } \\
\text { Python, } \\
\text { Mindstorms }\end{array}$ \\
\hline
\end{tabular}

\section{Table 2 CoderDojo Profiles}

The data gathered from each of these locations is presented below in a series of tables.

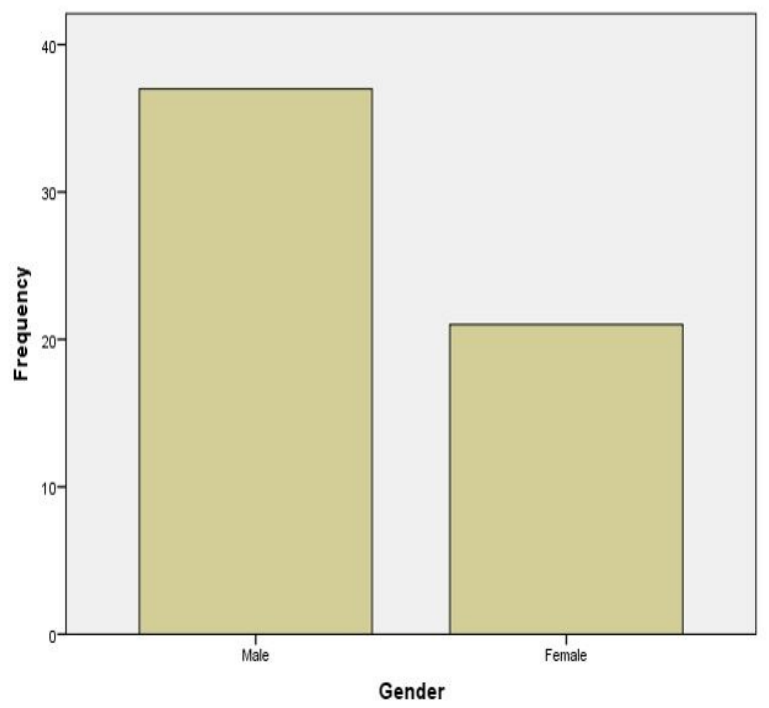

Figure 1 Gender split at CoderDojos

As Table 3 outlines, almost twice as many males (37) as females (21) attended CoderDojos in the area.

\begin{tabular}{l|ll}
$n$ & Gender & Mean Age \\
\hline 37 & Male & 10.7 \\
21 & Female & 10.6 \\
58 & &
\end{tabular}

\section{Table 23 Frequency Table - Gender across 4 CoderDojos}

With $63.7 \%$ of the CoderDojos male and $36.3 \%$ comprised of females, the results are somewhat significant in that there are almost 6\% more females present in the sampled CoderDojos than is reported by the CoderDojo Foundation (CoderDojo, 2015). Males tend to dominate mainstream Computing related disciplines (McKelvey, 2013), however CoderDojos appear to be bridging the gap.

The following table outlines the frequency of males and females in each individual CoderDojo researched.

\begin{tabular}{l|lll} 
CoderDojo & $N$ & Gender & $\%$ \\
\hline$A$ & 10 & Male & $58.8 \%$
\end{tabular}




\begin{tabular}{|c|c|c|c|}
\hline & 7 & Female & $41.2 \%$ \\
\hline \multirow[t]{2}{*}{$B$} & 12 & Male & $85.7 \%$ \\
\hline & 2 & Female & $14.3 \%$ \\
\hline \multirow[t]{2}{*}{ C } & 8 & Male & $47 \%$ \\
\hline & 9 & Female & $53 \%$ \\
\hline \multirow[t]{3}{*}{$D$} & 7 & Male & $70 \%$ \\
\hline & 3 & Female & $30 \%$ \\
\hline & $\underline{58}$ & & \\
\hline
\end{tabular}

\section{Table 4 Gender breakdown per CoderDojo}

As can be seen in the table above, all the CoderDojos with the exception of $C$, have more males than females. It is worth noting however, that CoderDojo $C$ is located in a school and the Dojo runs during class time making attendance compulsory. Therefore, it can be assumed that those figures merely represent a typical classroom gender split as opposed to a CoderDojo composition.

Consent was obtained from 100\% of the children (and their parents) to complete the Grit Survey. Grit scores could range from $>=0$ to $<=5$ with 5 denoting the highest grit score achievable.

\begin{tabular}{l|llll}
$n$ & Gender & $\begin{array}{l}\text { Mean } \\
\text { Grit }\end{array}$ & SD & Median \\
Score & & \\
\hline 37 & Male & 3.3 & 0.625 & 3.3 \\
21 & Female & 3.2 & 0.650 & 3.1 \\
58 & & & &
\end{tabular}

\section{Table 5 Frequency Table - Mean and Median Grit Scores across 4 CoderDojos}

The mean GRIT SCORE among females was 3.2 with a standard deviation of 0.650 . Males had a mean GRIT SCORE of 3.3 and a standard deviation of 0.625 . With less than $1 \%$ difference between the mean GRIT SCORE of males and females, it cannot be assumed that one gender has greater tenacity than another across the CoderDojos sampled. In order to test this further an Independent Samples T-Test was conducted. The null hypothesis that there is no relationship between gender and GRIT SCORE was upheld as no statistical significance was found between the variables $(\mathrm{p}=0.550, \mathrm{t}=0.172, \mathrm{df}=56)$.

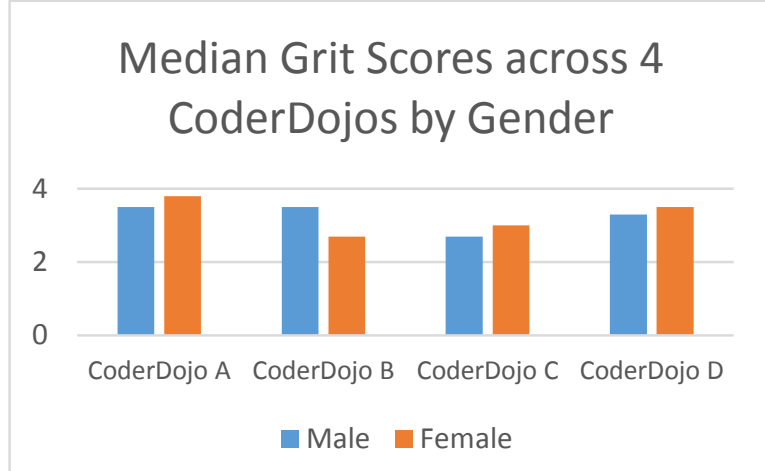

Figure 2 Median Grit scores by gender across four CoderDojos 
Figure 2 demonstrates the potential for other factors to effect grit levels among children at different locations. The graph is in contrast to the overall median grit scores reported in Table 5 where all scores are compared as a single set of data. It further serves to highlight the need to probe deeper into the children's own perceptions and opinions of CoderDojos by qualitative means.

At this conjuncture, it is difficult to draw conclusions. There are too many potentially confounding variables with respect to the Grit scores to make the results relevant. For example, it is not possible to tell whether or not the actual CoderDojo experience was the mitigating circumstance for the participants' Grit scores. With this in mind, the analysis of pre and post Grit scores at a Control Group(s) is required.

\section{Pre and Post CoderDojo Grit Analysis}

Null hypothesis: There is no difference in mean pre and post Grit scores.

\section{Paired Samples T-test}

There is evidence at CoderDojo $E$ (a primary school setting with Computing students as tutors) ( $\mathrm{t}=-2.444, \mathrm{p}=0.035$ ) that exposure to a CoderDojo can positively impact Grit scores among participants. In this data set $(n=11)$, it improved marks, on average, by approximately 0.21 points $(4.3 \%)$. With small numbers it is worth considering whether this is statistically significant or simply practically important. Pre and post Grit score analysis is required in other locations to determine the significance.

\section{Conclusions}

Grit can be described as a measurement of tenacity or a measure of how determined someone is. In a CoderDojo setting, grit is the likelihood of a child sticking with a problem rather than giving up. Their determination might be attributed to the environment, their tutors or the agency given to their learning. Additionally, the technologies utilised may serve to either foster that engagement or indeed stifle it.

Duckworth and Gross (2014) outline that typically those who are gritty (score of $>=3$ ) are more self-controlled. However, the correlation between these characteristics is not perfect as some individuals are paragons of grit but not self-control. Whereas others may exhibit signs of being exceptionally well-regulated but are not gritty.

The initial research conducted as part of this study has revealed a cohort of children with grit scores typically greater than 3 , indicating a learning environment comprising of individuals exhibiting traits of high determination and self-control. The data also reveal that there were no significant differences in grit scores between genders of those attending the four CoderDojos. The CoderDojo environment promotes the need for grit due to its informal, unstructured, selfdirected nature and the requirement that Ninja's work independently or as part of a team on their own goals/tasks.

Further research is required on the extent to which the Ninja's are self-selecting as the higher grit scores indicate a desire to be self-directed which is more easily accommodated in a CoderDodjo than school classroom. As a result, qualitative data from focus groups will add validity to the findings by triangulating the quantitative data with the children's own words and opinions.

Another possible area for future research involves addressing the applicability of CoderDojo environments with younger children. The CoderDojo dimensions of tutor support, the promotion of mutual respect, promoting task-related interaction, and not promoting performance goals are arguably vital for learner at all levels. Additional research may also yield answers pertaining to the levels of resilience and tenacity associated with positive educational environments and the impact of perceived tutor support in contributing to learner 
success. A future study might also determine whether the positive environment of a CoderDojo can impact upon other areas of a child's life.

\section{REFERENCES}

Banning, M. (2005). Approaches to teaching: current opinions and related research. Nurse Education Today. 25 (7). p502.508.

Baum, J. and Locke, E. (2004). The relationship of entrepreneurial traits, skill, and motivation to subsequent venture growth. Journal of Applied Psychology. 89. p587-598.

Blackbourn, J., Bunch, D., Fillingim, J., Thomas, c., Schillinger, D. and Dupree, J. (2011). Challenging orthodoxy: problem based learning in preservice teacher training. Journal of Instructional Psychology. 38 (3/4).

Boyer, L., Roth, W. and Lee, Y. (2003). Knowledge flow in salmonid enhancement: A study in social:material topologies. Society for Social Studies of Science (4S) Annual Meeting, Atlanta. Bridges, E. and Hallinger, P. (1995). Problem Based Learning in Leadership Development. Eugene, OR: University of Oregon.

CoderDojo. (2015). CoderDojo. Available: https://coderdojo.com/. Last accessed $19^{\text {th }}$ July 2015.

Connolly, P. (2007). Quantitative Data Analysis in Education: A critical introduction using SPSS. London and New York: Routledge.

Crebbin, W. (2004). Quality Teaching and Learning - Challenging Orthodoxies. New York: Peter Lang Publishing.

Dib, C. (1988). Formal, Non-Formal and Informal Education: Concepts/Applicability. Available: http://www.techne-dib.com.br/downloads/6.pdf. Last accessed 24 $4^{\text {th }}$ March 2016.

Downes, S. (2006). Learning networks and connective knowledge. Available:

http://itforum.coe.uga.edu/paper92/paper92.html. Last accessed 21st February 2016.

Duckworth, A. and Gross, J. (2014). Self-control and grit: Related but separable determinants of success. Current Directions in Psychological Science. 23(5). p319-325.

Duckworth, A., Peterson, C., Matthews, M. and Kelly, D. (2007). Grit: Perseverance and passion for long-term goals. Journal of Personality and Social Psychology. 9. p1087-1101. Duckworth, A. and Quinn, P. (2009). Development and validation of the Short Grit Scale (GRIT-S). Journal of Personality Assessment. 91(2). p166-174.

Eccles, J. and Barber, B. (1999). Student council, volunteering, basketball, or marching band: What kind of extracurricular involvement matters? Journal of Adolescent Research. 14. p1043.

Fredricks, J. and Eccles, J. (2006). Is extracurricular participation associated with beneficial outcomes? Concurrent and longitudinal relations. Developmental Psychology. 4 (4). p698-713. 
Gartner, W., Gatewood, E., and Shaver, K. (1991). Reasons for starting a business: Not-sosimple answers to simple questions. In: Hills, G. and LaForge, R. Research at the marketing/entrepreneurship interface. Chicago: University of Illinois at Chicago. Garry, R. (1963). The Psychology of Learning. New York: Center for Applied Research in Education.

Gerstein, J. (2013). Grit: The Other 21st Century Skills. Available:

https://usergeneratededucation.wordpress.com/2013/06/01/grit-the-other-21st-century-skills/. Last accessed 27th August 2015.

Goldstone, R., Landy, D. and Son, J. (2008). A well-grounded education: The role of perception in science and mathematics. In: Glenberg, A., DeVega, M. and Graesser, S. Proceedings of the Garachico Workshop on Symbols, Embodiment and Meaning. Gorman, M. (2007). Web 2.0: The sleep of reason, Part I. Available: http://blogs.britannica.com/2007/06/web-20-the-sleep-of-reason-part-i/. Last accessed $21^{\text {st }}$ February 2016.

Gregory, G. and Chapman, C. (2002). Differentiated Instructional Strategies: One Size Doesn't Fit All. Thousand Oaks, CA: Corwin Press.

Hoppers, W. (2006). Non-formal education and basic education reform: a conceptual review. International Institute for Educational Planning. Available http://www.unesco.org/iiep/PDF/pubs/K16.pdf. Last accessed 31st March 2016. Howe, M. (1999). Genius explained. New York: Cambridge University Press. International Technology Engineering Educators Association (ITEEA) (2000). Standards for Technological Literacy. Available: http://www.iteea.org/. Last accessed 8th January 2016. Keen, A. (2007). The cult of the amateur: How today's internet is killing our culture. New York: Currency/Doubleday.

Kouritzin, S., Piquemal, N. and Norman, R. (2009). Qualitative Research: Challenging the Orthodoxies in Standard Academic Discourse(s). Routledge.

Kress, G., and Pachler, N. (2007). Thinking about the ' $M-$ ' in Mobile Learning. In Norman, A. and Pearce, J. (Eds.). Conference proceedings: Long and short papers. 6th Annual Conference on Mobile Learning. p199 - 209.

Lind, A. (2002). ABLE policies in an international perspective. International Conference on Adult Basic and Literacy Education (ABLE) in the SADC Region. University of Natal. Lufti, D. and Cohen, A. (1987). A scale for measuring persistence in children. Journal of Personality Assessment. 51 (2). p178-185.

McKelvey, N. (2013). An Exploratory Study of Gender Imbalances and Stereotypes in Computer Science. International Journal of Information Studies. 5 (2). p66-85. 
Montuori, A. (1998). Creative inquiry: From instrumental knowing to love of knowledge. In: Petrankar, A. Light of Knowledge. Oakland: Dharma Publishing.

Morf, M. and Weber, W. (2000). I/O Psychology and the Bridging Potential of A. N. Leont'ev's Activity Theory. Canadian Psychology May. 41. p81-93.

Morrissey, K. (2005). The relationship between out-of-school activities and positive youth development: An investigation of the influences of communities and family. Adolescence. 40. p67-85.

National Academy of Engineering and National Research Council (NAENRC). (2002).

Technically Speaking: Why All Americans Need to Know More About Technology.

Washington, DC: The National Academies Press. Available:

http://www.nap.edu/catalog/10250/technically-speaking-why-all-americans-need-to-knowmore-about. Last accessed 8th January 2016.

National Research Council (NRC). (1999). Being Fluent with Information Technology from National Research Council. Available: http://www.nap.edu/read/6482/chapter/1. Last accessed 8th January 2016.

Oxenham, J., Diallo, A., Katahoire, A., Petkova-Mwangi, A., and Sall, O. (2002). Skills and literacy training for better livelihoods: a review of approaches and experiences. Report of a study for the Africa Region. Washington, DC: World Bank.

Patel, N. (2003). A Holistic Approach to Learning and Teaching Interaction: Factors in the Development of Critical Learners. The International Journal of Educational Management. 17 (6/7). p272-284.

Paul, R. and Elder, L. (2005). The Nature and Function of Critical and Creative Thinking. Dillon Beach, CA: Foundation for Critical Thinking.

Resnick, M. (2002). Rethinking Learning in the Digital Age. In: Kirkman, G. The global information technology report: Readiness for the networked world. Oxford, UK: Oxford University Press.

Rogers, A. (2004). Non-formal education: flexible schooling or participatory education? (CERC Studies in Comparative Education 15). Comparative Education Research Centre. The University of Hong Kong.

Siemens, G. (2006). Knowing knowledge. Canada: Lulu Press.

Siemens, G. (2008). New structures and spaces of learning: The systemic impact of connective knowledge, connectivism, and networked learning. Available:

http://elearnspace.org/Articles/systemic_impact.htm. Last accessed 21st February 2016.

Tight, M. (1996). Key Concepts in Adult Education and Training. Routledge: London. 
Torres, R. (2003). Lifelong learning: a new momentum and a new opportunity for adult basic learning and education (ABLE) in the South. Study commissioned by Sida's Education Division (New Education Division).

Vallerand, R., Blanchard, C., Mageau, G., Koestner, R., Ratelle, C. and Leonard, M., et al. (2003). Les passions de l'A^me: On obsessive and harmonious passion. Journal of Personality and Social Psychology. 85. p756-767.

Ward, T., Sawyer, F., McKinney, L. and Dettoni, J. (1974). Effective Learning: Lessons To Be Learned From Schooling, In: Ward, T. and Herzog, W. Effective learning in Non-Formal Education. East Lansing: Michigan State University.

Wiley, J. and Jee, B. (2011). Cognition: Overview and Recent Trends. In: Aukrust, V. G Learning and Cognition in Education. Oxford: Elsevier Limited. p3-8.

Wilson, N. and McClean, S. (1994). Questionnaire Design: A Practical Introduction. University of Ulster.

Wirfs-Brock, R. and Johnson, R. (1990). A survey of current research in object-oriented design. Communications of the ACM.

Yardi, S. and Bruckman, A. (2007). What Is Computing? Bridging the Gap Between Teenagers' Perceptions and Graduate Students' Experiences. Proceedings of the Third international Workshop on Computing Education Research. p39-50. 